\title{
Tailoring the Glass Composition to Increase the Thermal Stability without Impacting the Crystallization Behavior of Oxyfluorophosphate Glass
}

\author{
Nirajan Ojha ${ }^{1}$, Iuliia Dmitrieva ${ }^{1}$, Wilfried Blanc ${ }^{2} \mathbb{D}$ and Laeticia Petit ${ }^{1, *} \mathbb{C}$ \\ 1 Photonics Laboratory, Tampere University, Korkeakoulunkatu 3, FI-33720 Tampere, Finland; \\ ojhanirajan@gmail.com (N.O.); jula2801@gmail.com (I.D.) \\ 2 Institut de Physique de Nice, UMR7010 CNRS, Université Côte d'Azur, Parc Valrose, CEDEX 2, \\ 06018 Nice, France; wilfried.blanc@inphyni.cnrs.fr \\ * Correspondence: laeticia.petit@tuni.fi
}

check for updates

Citation: Ojha, N.; Dmitrieva, I.; Blanc, W.; Petit, L. Tailoring the Glass Composition to Increase the Thermal Stability without Impacting the Crystallization Behavior of Oxyfluorophosphate Glass. Ceramics 2021, 4, 148-159. https://doi.org/ 10.3390 /ceramics 4020013

Academic Editors: Gilbert Fantozzi and Enrico Bernardo

Received: 15 March 2021

Accepted: 14 April 2021

Published: 16 April 2021

Publisher's Note: MDPI stays neutral with regard to jurisdictional claims in published maps and institutional affiliations.

Copyright: (c) 2021 by the authors. Licensee MDPI, Basel, Switzerland. This article is an open access article distributed under the terms and conditions of the Creative Commons Attribution (CC BY) license (https:/ / creativecommons.org/licenses/by/ $4.0 /)$.

\begin{abstract}
Even though the ( $\left.75 \mathrm{NaPO}_{3}-25 \mathrm{CaF}_{2}\right)$ (in mol\%) glass can be heat-treated into transparent glass-ceramic with $\mathrm{Er}^{3+}$ doped $\mathrm{CaF}_{2}$ crystals precipitating in the volume of the glass during heattreatment, this glass was found to be a poor glass former, limiting its use as upconverter under $975 \mathrm{~nm}$ pumping. In this study, the impact of the glass composition on the thermal, optical and structural properties of the glass was investigated in order to understand how the glass composition can be tailored for the development of thermally stable upconverter glass-based material. The addition of $\mathrm{MgO}, \mathrm{Fe}_{2} \mathrm{O}_{3}$ and $\mathrm{Al}_{2} \mathrm{O}_{3}$ in the $\mathrm{NaPO}_{3}-\mathrm{CaF}_{2}$ glass system increases the thermal stability of glass due to the depolymerization of the glass network. However, the changes in the glass composition also impacted on the nucleation and growth process. Indeed, $\mathrm{CaF}_{2}$ and other crystals were found in the newly developed glasses after heat-treatment leading to glass-ceramics with lower intensity of upconversion than the $\left(75 \mathrm{NaPO}_{3}-25 \mathrm{CaF}_{2}\right)$ glass-ceramic used as a reference. Glasses were also prepared with different concentrations of $\mathrm{Er}_{2} \mathrm{O}_{3}$ and $\mathrm{ErF}_{3}$. These glasses were found to be promising as not only are they thermally stable, but they also exhibit green and red emission with high intensity under $975 \mathrm{~nm}$ pumping due to $\mathrm{Er}^{3+}$ clustering.
\end{abstract}

Keywords: crystallization; upconversion; oxyfluorophosphate glass; glass-ceramic; thermal stability

\section{Introduction}

Oxyfluorophosphate glasses have been gaining interest in recent years due to the combined properties of oxides and fluorides. These glasses possess low phonon energy and they allow high solubility of rare-earth (RE) ions as RE clustering occurs at very high RE content [1]. Additionally, the composition of the oxyfluorophosphate glasses can be easily tailored so that the glasses can be engineered with good chemical durability and thermal stability [2].

As the spectroscopic properties of RE ions can be tailored by controlling the local environment of the RE ions, glass-ceramics can possess higher absorption and emission cross-sections and energy transfer rates compared to their parent glasses if the RE ions are located in crystals with specific crystalline phase [3,4]. Due to their promising spectroscopic properties, RE doped GCs have found extensive use for numerous applications in optics, photonics, dental and bioactive fields, for example [5-7]. To be considered promising materials for these applications, the crystals should be homogeneously distributed in the volume of the glass matrix. Additionally, the crystals should be smaller than the incident light wavelength and they should have a similar refractive index than the glassy host for the glass-ceramic to be transparent. Therefore, the control of the growth of crystals with tailored composition, size and segregation within the volume of the glass is crucial especially for the technology related to transparent glass-ceramics. 
Most studies on the development of new transparent GCs have been focused on silicate glasses. Wang and Ohwaki reported the first transparent RE doped GCs in 1993 [8]; $\mathrm{The} \mathrm{Er}^{3+}, \mathrm{Yb}^{3+}$ codoped transparent glass-ceramic was reported with an upconversion efficiency higher than the parent glass due to the precipitation of $(\mathrm{Pb}, \mathrm{Cd}) \mathrm{F}_{2}$ crystalline phase. Enhancement of the upconversion luminescence was also reported in transparent $\mathrm{Er}^{3+}$ doped oxyfluoride aluminosilicate glass-ceramics due to the $\mathrm{Er}^{3+}$ doped $\mathrm{CaF}_{2}$ crystals precipitating in the volume of the glass [9]. Studies on transparent germanate and tellurite GCs have been also reported [10-13]. However, surprisingly, fewer studies can be found on transparent phosphate GCs.

Transparent glass-ceramics in the $\mathrm{NaPO}_{3}-\mathrm{CaF}_{2}$ system were successfully prepared with enhanced upconversion properties compared to the base glasses, due to the volume precipitation of $\mathrm{Er}^{3+}$ doped $\mathrm{CaF}_{2}$ crystals occurring during heat-treatment [14]. The onset of crystallization was reported to be largely different than the maximum nucleation temperature of glasses, independently of the glass composition, indicating that the nucleation and growth of the crystals can be controlled. Thus, transparent glass-ceramics can be obtained from this glass-system. However, glasses in this system possess low thermal stability against crystallization as evidenced by the low temperature difference between the crystallization and the glass transition temperatures. Thus, this glass has a high tendency to crystallize during heat treatment. One should remind that thermal stability is an important property the glass should possess for many applications, especially for the development of novel optical fibers, for example [15]. Indeed, uncontrolled crystallization could occur during the fiber drawing process of a poor glass former. Thus, it is important to advance the fundamental understanding of the impact of the glass composition on the thermal stability of glasses, especially of glasses within the $\mathrm{NaPO}_{3}-\mathrm{CaF}_{2}$ system, in order to develop promising transparent GCs. These GCs are of great interest not only from an optical fiber perspective but also with a view to finding new applications, for example for waste immobilization [16] or as sealing glasses [17,18]. Additionally, these GCs are promising upconverter materials which could be used to increase the efficiency of the solar cells $[19,20]$.

The goal of this study is to understand how to tailor the glass composition in order to increase the thermal stability of the glass without modifying the volume precipitation of $\mathrm{Er}^{3+}$ doped $\mathrm{CaF}_{2}$ crystals inside the glass during heat-treatment, and so its upconversion property. Here, new glasses in the $\mathrm{NaPO}_{3}-\mathrm{CaF}_{2}$ glass system were prepared to investigate the effect of the glass composition on the thermal, optical, structural and crystallization properties.

\section{Materials and Methods}

The compositions of the investigated oxyfluorophosphate glasses are $(100-\mathrm{x}-0.25)$ $\left(75 \mathrm{NaPO}_{3}-25 \mathrm{CaF}_{2}\right)-\mathrm{x}\left(\mathrm{MgO} / \mathrm{Al}_{2} \mathrm{O}_{3} / \mathrm{Fe}_{2} \mathrm{O}_{3}\right)-0.25 \mathrm{Er}_{2} \mathrm{O}_{3}$ (in mol\%) with $\mathrm{x}$ ranging from 0 to 6 and (100- y) $\left(75 \mathrm{NaPO}_{3}-25 \mathrm{CaF}_{2}\right)-\mathrm{y}\left(\mathrm{Er}_{2} \mathrm{O}_{3} / \mathrm{ErF}_{3}\right)$ (in $\left.\mathrm{mol} \%\right)$ with y ranging from 0.25 to 6 . The composition of the glasses and their corresponding code are summarized in Table 1.

The glasses were prepared in air using standard melting condition. Platinum (Pt) crucible was used for the preparation of the $\mathrm{Mg}$ and $\mathrm{Al}$ glasses while the Fe glasses were prepared in an alumina crucible. The glass with $\mathrm{x}=0$ prepared in Pt crucible is labelled as $0 \mathrm{Mg} / \mathrm{Al}$, while it is labeled $0 \mathrm{Fe}$ when prepared in alumina crucible. $\mathrm{NaPO}_{3}$ (technical grade), $\mathrm{CaF}_{2}(99 \%), \mathrm{ErF}_{3}(99.9 \%) \mathrm{Er}_{2} \mathrm{O}_{3}(99.9 \%), \mathrm{MgO}(\geq 99 \%), \mathrm{Fe}_{2} \mathrm{O}_{3}(\geq 99 \%)$ and $\mathrm{Al}_{2} \mathrm{O}_{3}$ $(99 \%)$ were used as raw materials. The glasses were melted for 5 min between 900 and $1025^{\circ} \mathrm{C}$ depending on the glass composition. After quenching in air, the glasses were annealed $40^{\circ} \mathrm{C}$ below their respective glass transition temperature $\left(T_{g}\right)$ for $6 \mathrm{~h}$. The glasses were polished prior to the heat-treatment for $17 \mathrm{~h}$ at $20^{\circ} \mathrm{C}$ above their $\mathrm{T}_{\mathrm{g}}$ and then at their crystallization temperature $\left(T_{p}\right)$ for $1 \mathrm{~h}$.

The glass transition temperature $\left(\mathrm{T}_{\mathrm{g}}\right)$, the onset of the crystallization $\left(\mathrm{T}_{\mathrm{x}}\right)$ and the crystallization temperature $\left(\mathrm{T}_{\mathrm{p}}\right)$ were determined using differential thermal analysis (DTA) 
(TA instruments SDT Q600). The heating rate was $10{ }^{\circ} \mathrm{C} / \mathrm{min}$. Platinum pan and $\mathrm{N}_{2}$ atmosphere were used for the measurement. $\mathrm{T}_{\mathrm{g}}$ was taken at the inflection point of the endotherm, $T_{p}$ at the maximum of the exothermic peak and $T_{x}$ at the onset of the crystallization peak. The accuracy of the measurement is $\pm 3{ }^{\circ} \mathrm{C}$.

Table 1. Composition (in mol\%) and code of the investigated glasses.

\begin{tabular}{cccccccc}
\hline Glass Code & $\mathbf{N a P O}_{3}$ & $\mathrm{CaF}_{2}$ & $\mathrm{Al}_{2} \mathbf{O}_{3}$ & $\mathbf{M g O}$ & $\mathrm{Fe}_{2} \mathbf{O}_{3}$ & $\mathrm{Er}_{2} \mathbf{O}_{3}$ & $\mathrm{ErF}_{3}$ \\
\hline $0 \mathrm{Mg} / \mathrm{Al}$ & 74.8 & 24.9 & & & & 0.25 & \\
$1.5 \mathrm{Mg}$ & 73.7 & 24.6 & & 1.50 & & 0.25 & \\
$3 \mathrm{Mg}$ & 72.6 & 24.2 & & 3.00 & & 0.25 & \\
$4.5 \mathrm{Mg}$ & 71.4 & 23.8 & & 4.50 & & 0.25 & \\
$6 \mathrm{Mg}$ & 70.3 & 23.4 & & 6.00 & & 0.25 & \\
$0.5 \mathrm{Al}$ & 74.4 & 24.8 & 0.50 & & & 0.25 & \\
$1 \mathrm{Al}$ & 74.1 & 24.7 & 1.00 & & & 0.25 & \\
$1.25 \mathrm{Al}$ & 73.9 & 24.6 & 1.25 & & & 0.25 & \\
\hline $1 \mathrm{Er}_{2} \mathrm{O}_{3}$ & 74.3 & 24.8 & & & & 2.00 & \\
$2 \mathrm{Er}_{2} \mathrm{O}_{3}$ & 73.5 & 24.5 & & & & 3.00 & \\
$3 \mathrm{Er}_{2} \mathrm{O}_{3}$ & 72.8 & 24.2 & & & & & 0.5 \\
\hline $0.5 \mathrm{ErF} 3_{3}$ & 74.6 & 24.9 & & & & & 2.0 \\
$2 \mathrm{ErF}$ & 73.5 & 24.5 & & & & & 6.0 \\
$4 \mathrm{ErF}$ & 72.0 & 24.0 & & & & & \\
$6 \mathrm{ErF}$ & 70.5 & 23.5 & & & & 0.25 & \\
\hline $0 \mathrm{Fe}$ & 74.8 & 24.9 & & & 0.5 & 0.25 & \\
$0.5 \mathrm{Fe}$ & 74.4 & 24.8 & & & 1.0 & 0.25 & \\
$1 \mathrm{Fe}$ & 74.1 & 24.7 & & & &
\end{tabular}

Perkin Elmer Spectrum FTIR2000 spectrometer with Attenuated Total Reflection (ATR) mode was used to obtain the IR spectra of the glasses. For this measurement, the samples were crushed into powder. The IR spectra were recorded between $650 \mathrm{~cm}^{-1}$ and $1500 \mathrm{~cm}^{-1}$ with a resolution of $2 \mathrm{~cm}^{-1}$ and 8 scan accumulation.

Panalytical EMPYREAN multipurpose X-ray Diffractometer (XRD) with Nickel filtered $\mathrm{Cu}-\mathrm{K}_{\alpha}$ radiation was used to determine the crystal phases in the heat-treated glasses. The spectra were obtained using the Bragg-Brentano geometry and by rotating the sample holder around the Phi-axis at a constant speed of 16 revolutions per minute. The scan range was from $20^{\circ}$ to $80^{\circ}$ using a step size of 0.026 . The MAUD software was used to analyze the XRD-patterns of the heat-treated glasses.

The upconversion spectra of the glasses were measured from glasses crushed into powder to allow one to compare the intensity of the emission between the samples. The glasses were excited using a TEC-cooled fiber-coupled multimode laser (II-VI Laser Enterprise) with a center emission wavelength $\left(\lambda_{\text {exc }}\right)$ at $\sim 975 \mathrm{~nm}$ and power of $\sim 23.5 \mathrm{~mW}$. The spectra were measured using a Spectro 320 optical spectrum analyzer equipped with a photomultiplier tube capable of measuring wavelengths between $500 \mathrm{~nm}$ and $700 \mathrm{~nm}$ (Instrument Systems Optische Messtechnik GmbH, Munich, Germany) at room temperature. The luminescence light was collected from the samples to the spectrum analyzer using a lens and a liquid light guide.

\section{Results and Discussion}

Recently, the nucleation and growth behavior of glasses in the $\mathrm{NaPO}_{3}-\mathrm{CaF}_{2}$ system was reported by Ojha et al. [14]. A small addition of $\mathrm{TiO}_{2}, \mathrm{ZnO}$ or $\mathrm{MgO}(1.5 \mathrm{~mol} \%)$ was found to be enough to impact the nucleation and growth process: although $\mathrm{Er}^{3+}$ doped $\mathrm{CaF}_{2}$ crystals precipitate in all the glasses during heat-treatment, the Maximum Nucleation Temperature $\left(T_{n} \max \right)$ and the crystal growth rates were found to depend on the glass composition. However, the changes in the glass composition were too little to impact the thermal stability of the glasses. Thus, in this study, new glasses with a larger amount of 
$\mathrm{MgO}$ were investigated. Glasses were also prepared with $\mathrm{Al}_{2} \mathrm{O}_{3}$ and $\mathrm{Fe}_{2} \mathrm{O}_{3}$ as they were found to prevent the tendency of phosphate glasses in other systems to crystallize [21,22].

As shown in Table 2, $\mathrm{MgO}, \mathrm{Al}_{2} \mathrm{O}_{3}$ and $\mathrm{Fe}_{2} \mathrm{O}_{3}$ can be added in the $\mathrm{NaPO}_{3}-\mathrm{CaF}_{2}$ system to increase $\mathrm{T}_{\mathrm{g}}, \mathrm{T}_{\mathrm{x}}$ and $\mathrm{T}_{\mathrm{p}}$ - and more importantly to increase $\Delta \mathrm{T}\left(\Delta \mathrm{T}=\mathrm{T}_{\mathrm{x}}-\mathrm{T}_{\mathrm{g}}\right)$, which is used as a gauge to the glass resistance against crystallization. Thus, it is clearly shown here that the addition of $\mathrm{MgO}, \mathrm{Al}_{2} \mathrm{O}_{3}$ and $\mathrm{Fe}_{2} \mathrm{O}_{3}$ increases the thermal stability of the glass in the $\mathrm{NaPO}_{3}-\mathrm{CaF}_{2}$ system. While most of the $\mathrm{Mg}$ glasses are poor glass formers due to their low $\Delta \mathrm{T}\left(<90^{\circ} \mathrm{C}\right)$, the $\mathrm{Al}$ and $\mathrm{Fe}$ glasses can be considered as good glass formers due to their $\Delta \mathrm{T}$ larger than $90^{\circ} \mathrm{C}$.

Table 2. Thermal properties of the investigated glasses (NA: the peak intensity is too small to estimate the size of the crystallite).

\begin{tabular}{|c|c|c|c|c|c|c|}
\hline \multirow[b]{2}{*}{ Glass Code } & \multicolumn{4}{|c|}{ Thermal Properties } & \multirow{2}{*}{$\begin{array}{l}\text { Mean Size of the Crystallites } \\
\qquad \pm 2(\mathrm{~nm})\end{array}$} & \multirow{2}{*}{$\begin{array}{c}\mathrm{Er}^{3+} \text { Ions } / \mathrm{cm}^{3}\left(10^{19}\right) \\
\pm 5 \%\end{array}$} \\
\hline & $\begin{array}{c}\mathrm{T}_{\mathrm{g}} \\
\pm 3\left({ }^{\circ} \mathrm{C}\right)\end{array}$ & $\begin{array}{c}T_{x} \\
\pm 3\left({ }^{\circ} \mathrm{C}\right)\end{array}$ & $\begin{array}{r}\mathrm{T}_{\mathrm{p}} \\
\pm 3\left({ }^{\circ} \mathrm{C}\right)\end{array}$ & $\begin{array}{l}\Delta \mathrm{T}=\mathrm{T}_{\mathrm{x}}-\mathrm{T}_{\mathrm{g}} \\
\quad \pm 6\left({ }^{\circ} \mathrm{C}\right)\end{array}$ & & \\
\hline \multicolumn{7}{|c|}{ Prepared in Pt cucible } \\
\hline $0 \mathrm{Mg} / \mathrm{Al}$ & 269 & 323 & 338 & 54 & 17 & 8.19 \\
\hline $1.5 \mathrm{Mg}$ & 279 & 345 & 365 & 66 & 24 & 8.36 \\
\hline $3 \mathrm{Mg}$ & 290 & 377 & 410 & 87 & 30 & 8.43 \\
\hline $4.5 \mathrm{Mg}$ & 297 & 381 & 410 & 84 & 36 & 8.50 \\
\hline $6 \mathrm{Mg}$ & 302 & 381 & 405 & 79 & 45 & 8.61 \\
\hline $0.5 \mathrm{Al}$ & 281 & 378 & 420 & 97 & 30 & 8.31 \\
\hline $1 \mathrm{Al}$ & 295 & 393 & 420 & 98 & 41 & 8.31 \\
\hline $1.25 \mathrm{Al}$ & 299 & 399 & 429 & 100 & NA & 8.31 \\
\hline \multicolumn{7}{|c|}{ Prepared in alumina crucible } \\
\hline OFe & 270 & 343 & 360 & 73 & 18 & 8.19 \\
\hline $0.5 \mathrm{Fe}$ & 300 & 390 & 435 & 86 & 31 & 8.28 \\
\hline $1 \mathrm{Fe}$ & 330 & 499 & 538 & 169 & NA & 8.35 \\
\hline
\end{tabular}

One should notice that the $0 \mathrm{Mg} / \mathrm{Al}$ and $0 \mathrm{Fe}$ glasses exhibit different thermal properties, although these glasses have the same composition $\left(75 \mathrm{NaPO}_{3}-25 \mathrm{CaF}_{2}\right.$, in $\left.\mathrm{mol} \%\right)$. Their different thermal properties can be related to the crucibles used for the glass melting. Indeed, $1 \mathrm{~mol} \%$ of $\mathrm{Al}_{2} \mathrm{O}_{3}$ is expected in the $\mathrm{Fe}$ glasses due to the contamination from the alumina crucible occurring during the glass melting, as confirmed using SEM coupled with EDS. This confirms the increase in the thermal properties of the glass due to the addition of $\mathrm{Al}_{2} \mathrm{O}_{3}$ in the $\mathrm{NaPO}_{3}-\mathrm{CaF}_{2}$ system

In order to understand the different thermal properties of the investigated glasses, their structure was investigated using FTIR. The normalized IR spectra of the glasses are presented in Figure 1.

The IR spectra are similar to those reported in $[14,23]$ and a detailed attribution of the IR bands can be found in [24]. In summary, the progressive decrease in the intensity of the bands at 700, 950, 1000 and 1250 associated with the slight increase in the intensity of the shoulder at $1100 \mathrm{~cm}^{-1}$ as compared to the main band can be seen when $\mathrm{x}$ increases in the 3 glass systems. These changes indicate that the progressive addition of $\mathrm{MgO}, \mathrm{Al}_{2} \mathrm{O}_{3}$ and $\mathrm{Fe}_{2} \mathrm{O}_{3}$ leads to a depolymerization of the glass network associated with an increase in the $\mathrm{Q}^{1}$ units and a decrease in the $\mathrm{Q}^{2}$ units, the $\mathrm{Q}^{1}$ and $\mathrm{Q}^{2}$ units being units with 1 and 2 bridging oxygens per tetrahedron, respectively. $\mathrm{P}-\mathrm{O}-\mathrm{Fe} / \mathrm{Al} / \mathrm{Mg}$ bonds are also expected to form at the expense of P-O-P bonds, as suggested in [14,23]. Therefore, the addition of $\mathrm{MgO}, \mathrm{Al}_{2} \mathrm{O}_{3}$ and $\mathrm{Fe}_{2} \mathrm{O}_{3}$ is expected to lead to the distortion and compaction of the glass network. These changes in the glass structure associated with the progressive addition of $\mathrm{MgO}, \mathrm{Al}_{2} \mathrm{O}_{3}$ and $\mathrm{Fe}_{2} \mathrm{O}_{3}$ are in agreement with the increase in $\mathrm{T}_{\mathrm{g}}$ and also in the thermal stability of the glasses. Similar impact of the addition of $\mathrm{Al}_{2} \mathrm{O}_{3}$ and $\mathrm{Fe}_{2} \mathrm{O}_{3}$ on the structure and thermal stability of phosphate glasses were reported in [23,25]. One can notice that the changes in the IR spectra are more distinct when adding $\mathrm{Fe}_{2} \mathrm{O}_{3}$ than when adding 
$\mathrm{MgO}$ or $\mathrm{Al}_{2} \mathrm{O}_{3}$ in the network probably due to the $\mathrm{Al}$ contamination from the crucible as discussed earlier. Additionally, one should also mention that the structure of the Fe glasses is expected to be more polymerized compared to the other glasses, due to the fact that the $\mathrm{Fe}^{3+}$ ions could crosslink three oxygen more than that bonded to $\mathrm{Mg}^{2+}$ as reported in [26].

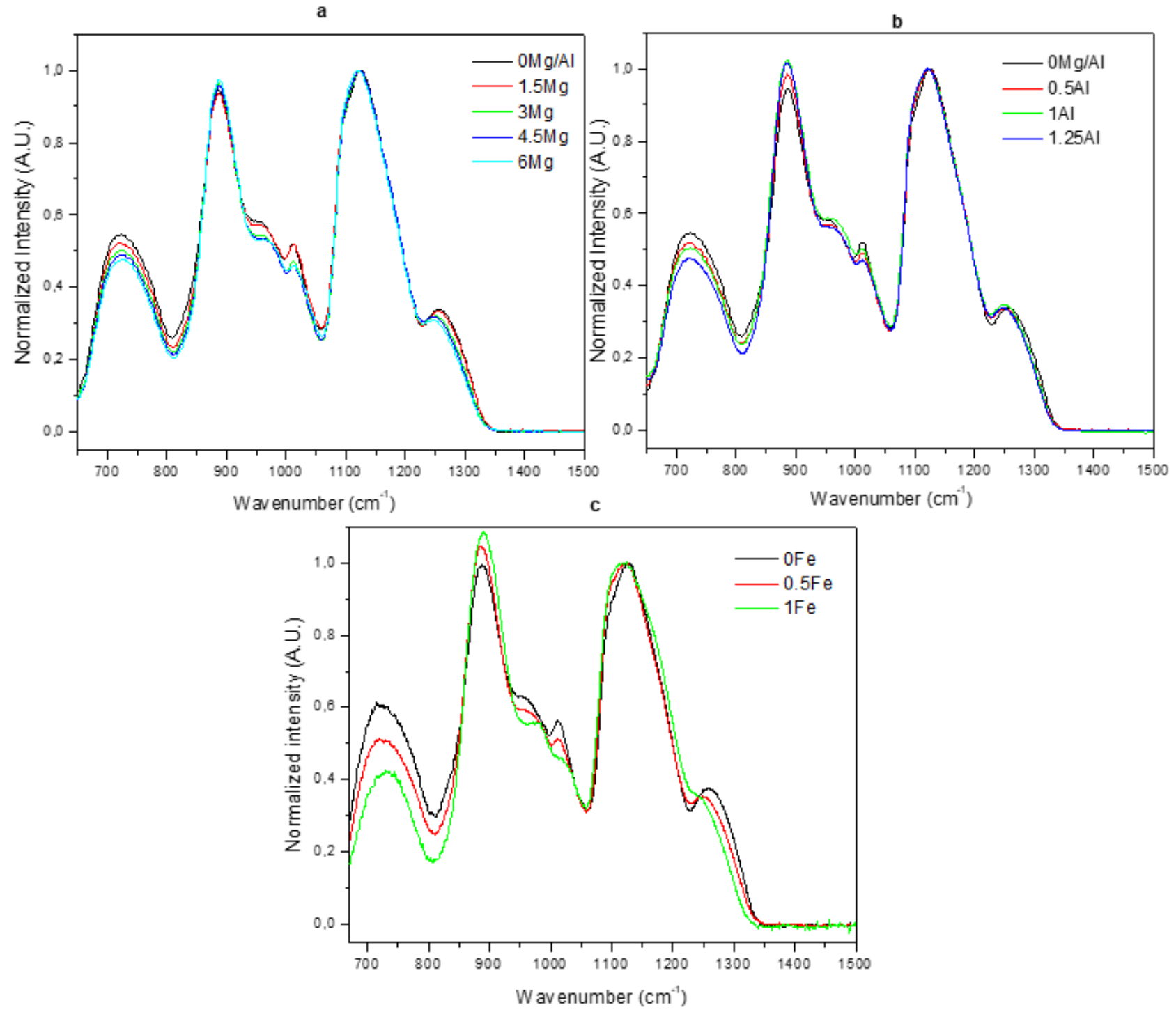

Figure 1. Normalized IR spectra of the investigated $\mathrm{Mg} \mathrm{(a)} \mathrm{Al} \mathrm{(b)} \mathrm{and} \mathrm{Fe}$ (c) glasses. The spectra are normalized to the maximum band at $1100 \mathrm{~cm}^{-1}$.

Despite the fact that the changes in the glass composition have a noticeable impact on the structure, the glasses exhibit similar absorption and cross-sections at $975 \mathrm{~nm}$ and $1.5 \mu \mathrm{m}$, measured at $\sim 2.01 \times 10^{-21} \mathrm{~cm}^{2}$ and $6.32 \times 10^{-21} \mathrm{~cm}^{2}$, respectively, indicating that the site of the $\mathrm{Er}^{3+}$ ions is similar in all the investigated glasses. Thus, $\mathrm{Al}, \mathrm{Mg}$ and $\mathrm{Fe}$ are not expected to be in the shell of $\mathrm{Er}^{3+}$ ions although they clearly have an impact on the phosphate network.

The glasses were heat-treated at $\left(T_{g}+20^{\circ} \mathrm{C}\right)$ for $17 \mathrm{~h}$ and at their respective $T_{p}$ for $1 \mathrm{~h}$ as performed in [14]. All the investigated glasses became translucent after heat-treatment. They look similar to those reported in [14]. The decrease in the transmittance was evidenced by the decrease in the transmittance of the heat-treated glasses (Figure 2).

The decrease in the transmittance property after heat-treatment can be related to the precipitation of crystals occurring during the heat-treatment, which was confirmed by 
measuring the XRD pattern of the glasses after heat-treatment. The XRD patterns of the heat-treated glasses, in Figure 3, exhibit peaks confirming the precipitation of crystals during heat-treatment.

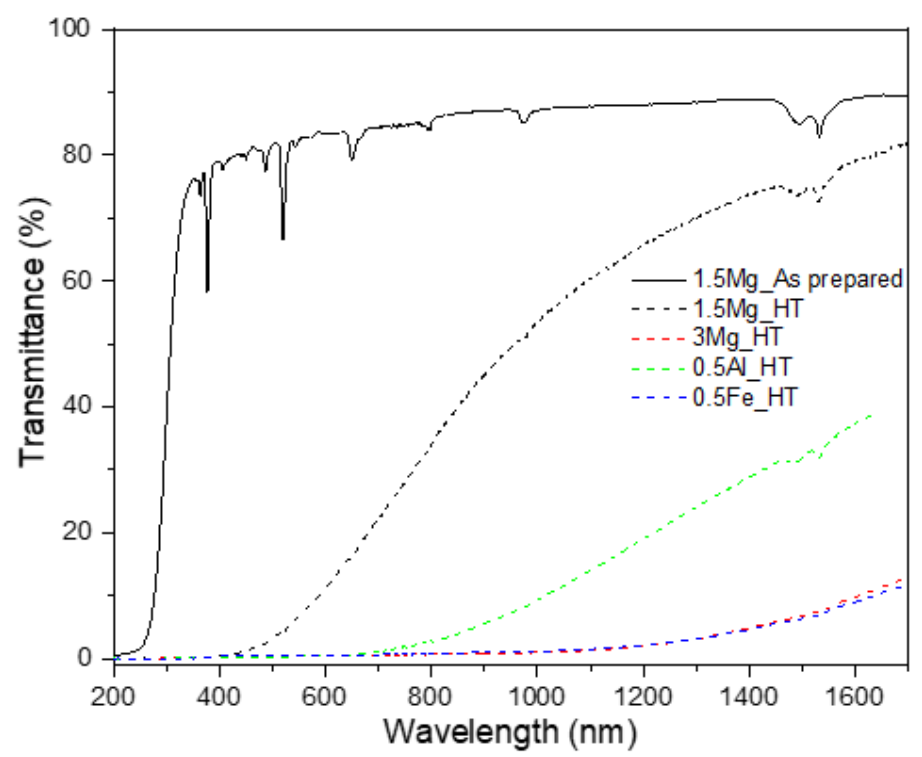

Figure 2. Transmittance spectrum of the as-prepared $1.5 \mathrm{Mg}$ glass taken as an example as all the as-prepared glasses exhibit similar transmittance spectra (solid line) and of some heat-treated (HT) glasses (dashed line).

Although $\mathrm{CaF}_{2}$ crystals (ICDD PDF \#00-035-0816) were found in all the glasses, other crystals such as $\mathrm{NaPO}_{3}$ (ICDD PDF\#04-011-3120) and $\mathrm{Na}_{2} \mathrm{Ca}_{2}\left(\mathrm{P}_{2} \mathrm{O}_{7}\right) \mathrm{F}_{2}$ (ICDD PDF\#04-0121844) were detected in the XRD pattern of the Al glasses and also in the XRD pattern of the $\mathrm{Mg}$ glasses with $\mathrm{x}>1.5 \mathrm{~mol} \% . \mathrm{Ca}_{2} \mathrm{P}_{2} \mathrm{O}_{7}$ crystals (ICDD PDF \#00-009-0345) are also suspected in the heat-treated $1 \mathrm{Fe}$ glass. Thus, it is shown here that the progressive addition of $\mathrm{MgO}, \mathrm{Al}_{2} \mathrm{O}_{3}$ and $\mathrm{Fe}_{2} \mathrm{O}_{3}$ promotes the precipitation of new crystals at the expense of $\mathrm{CaF}_{2}$ during heat-treatment. The precipitation of these new crystals is thought to be due to the distortion and compaction of the glass network induced by the addition of $\mathrm{MgO}$, $\mathrm{Al}_{2} \mathrm{O}_{3}$ and $\mathrm{Fe}_{2} \mathrm{O}_{3}$ as discussed earlier. The size of the crystallites size was determined by XRD using the following Scherrer's equation [27]:

$$
\mathrm{D}=\mathrm{K} \lambda / \beta \cos \theta
$$

where $\mathrm{K}=0.9$ is the numerical factor, $\lambda=0.154056 \mathrm{~nm}$ represents the wavelength of the $\mathrm{X}$-ray $(\mathrm{Cu} \mathrm{K} \alpha$ radiation), $\beta$ is the full width at half maximum of the X-ray diffraction peak in radians and $\theta$ is the Bragg angle. Here, the strongest diffraction peak at $2 \theta=47^{\circ}$, which corresponds to the (220) crystal planes, was used for the calculation.

As shown in Table 2, the crystallites grow in size as the concentration of $\mathrm{MgO}, \mathrm{Al}_{2} \mathrm{O}_{3}$ and $\mathrm{Fe}_{2} \mathrm{O}_{3}$ increases, which is in agreement with the decrease in the transmittance observed after heat-treatment (Figure 2). Similar growth of the crystallite size was reported when adding $1.5 \mathrm{~mol} \%$ of $\mathrm{TiO}_{2}, \mathrm{ZnO}$ and $\mathrm{MgO}$ in the base glass [14]. One should mention that the crystal volume fraction in all the heat-treated glasses-which is estimated from the ratio of integrating area of the peaks to total integrated area of the XRD patterns as in [28] -is about $(3.5 \pm 0.1) \%$, indicating that the decrease in the transmittance of the $\mathrm{Mg}, \mathrm{Al}$ and $\mathrm{Fe}$ glasses after heat-treatment can be related to the precipitation of different crystals and also to the precipitation of large crystals which cause strong light scattering.

The upconversion spectra of the glasses were measured prior to and after heattreatment and are depicted in Figure 4. 


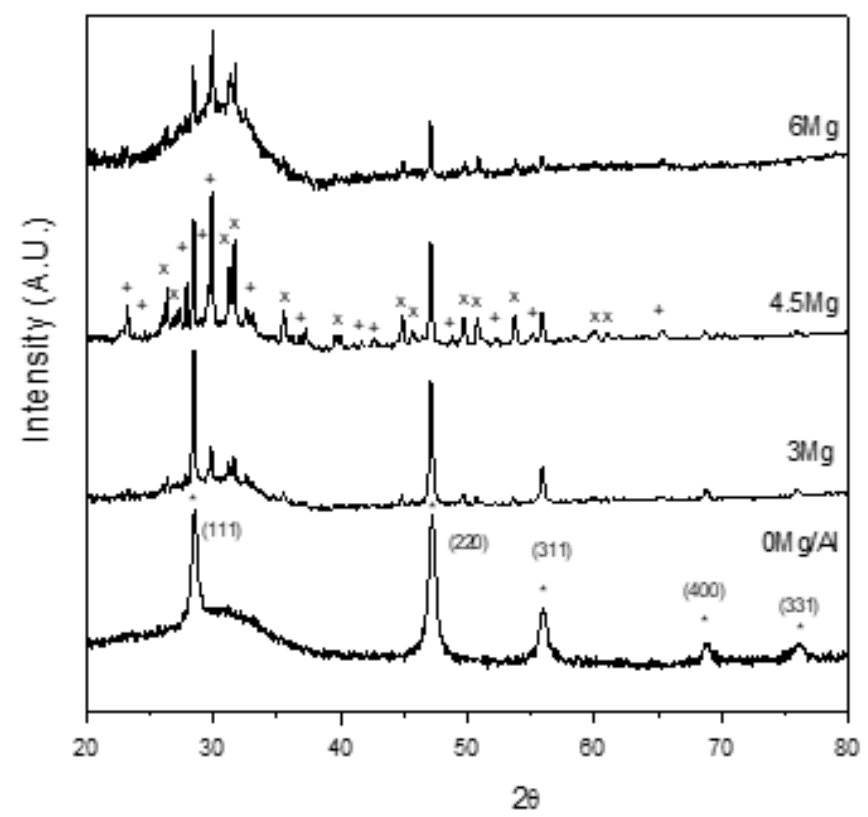

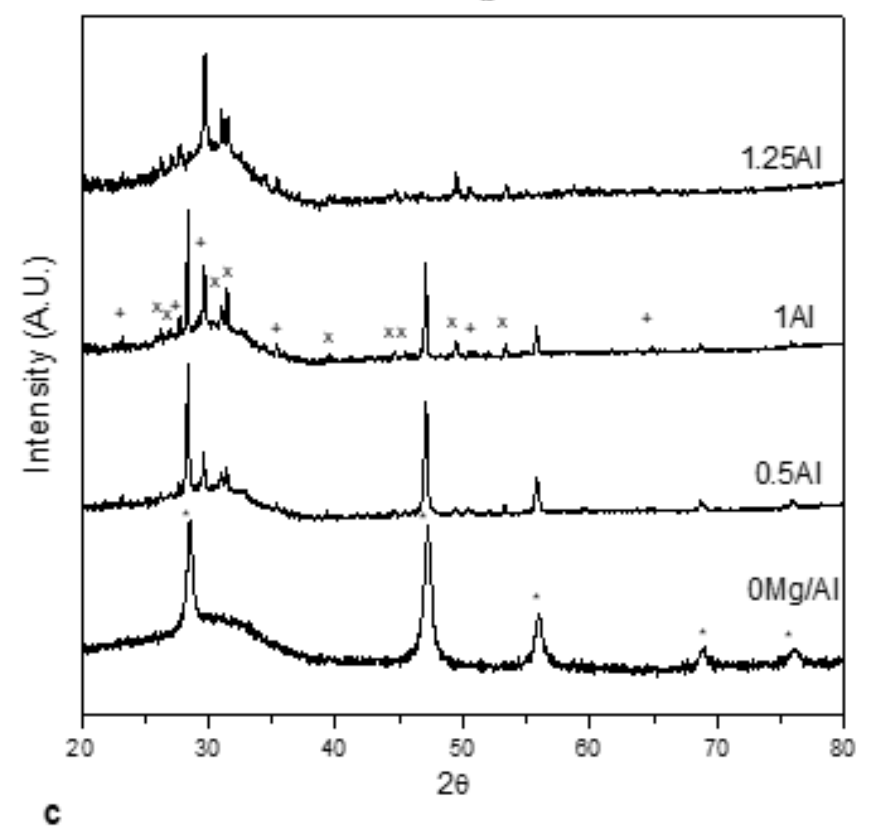

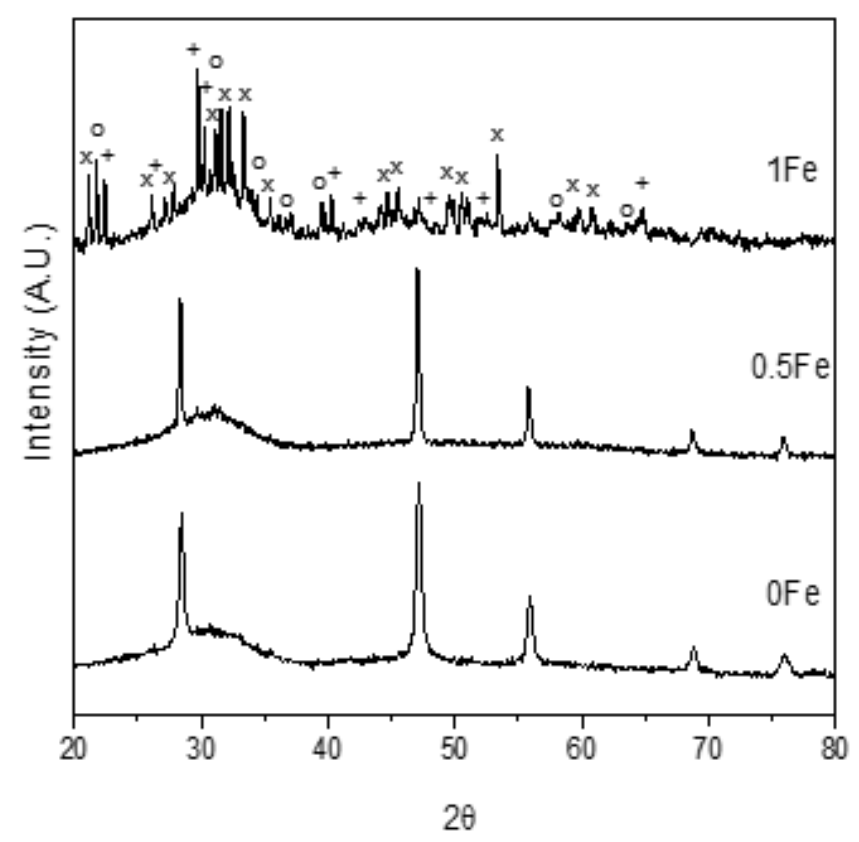

Figure 3. XRD spectra of the investigated glasses heat-treated at $\left(\mathrm{T}_{\mathrm{g}}+20^{\circ} \mathrm{C}\right)$ for $17 \mathrm{~h}$ and at $\mathrm{T}_{\mathrm{p}}$ for $1 \mathrm{~h} \mathrm{Mg}(\mathbf{a}) \mathrm{Al}(\mathbf{b})$ and Fe (c) [Peaks correspond to * $\mathrm{CaF}_{2}$ (ICDD PDF \#00-035-0816), + $\mathrm{NaPO}_{3}\left(\mathrm{ICDD}\right.$ PDF\#04-011-3120), $x \mathrm{Na}_{2} \mathrm{Ca}_{2}\left(\mathrm{P}_{2} \mathrm{O}_{7}\right) \mathrm{F}_{2}(\mathrm{ICDD}$ PDF\#04-012-1844), o $\mathrm{Ca}_{2} \mathrm{P}_{2} \mathrm{O}_{7}$ (ICDD PDF \#00-009-0345)].

The spectra exhibit green and red emission bands which correspond to ${ }^{2} \mathrm{H}_{11 / 2}$ (525 nm) ${ }^{4} \mathrm{~S}_{3 / 2}(550 \mathrm{~nm}) \rightarrow{ }^{4} \mathrm{I}_{15 / 2}$ and ${ }^{4} \mathrm{~F}_{9 / 2} \rightarrow{ }^{4} \mathrm{I}_{15 / 2}$ transitions of $\mathrm{Er}^{3+}$, respectively [29]. The heat-treatment increases significantly the intensity of the visible emission confirming the presence of $\mathrm{Er}^{3+}$ ions in the $\mathrm{CaF}_{2}$ crystals as explained in [14,30]. However, the increase in the intensity of the upconversion after heat-treatment depends on the glass composition: the newly heat-treated glasses exhibit lower intensity of upconversion than the heat-treated $0 \mathrm{Mg} / \mathrm{Al}$ glass. Thus, it is clearly shown that the progressive precipitation of the $\mathrm{NaPO}_{3}$, $\mathrm{Na}_{2} \mathrm{Ca}_{2}\left(\mathrm{P}_{2} \mathrm{O}_{7}\right) \mathrm{F}_{2}$ and/or $\mathrm{Ca}_{2} \mathrm{P}_{2} \mathrm{O}_{7}$ crystals at the expense of $\mathrm{CaF}_{2}$ crystals as $\mathrm{x}$ increases leads to lower intensity of upconversion.

Although the $0 \mathrm{Mg} / \mathrm{Al}$ and $0 \mathrm{Fe}$ glass are similar in composition, the heat-treated $0 \mathrm{Fe}$ glass exhibits lower intensity of upconversion confirming that the addition of $\mathrm{Al}_{2} \mathrm{O}_{3}$ in the 
$\mathrm{NaPO}_{3}-\mathrm{CaF}_{2}$ glass, due to the contamination from the alumina crucible discussed earlier, limits the precipitation of $\mathrm{CaF}_{2}$ crystals during the heat-treatment and so the increase in intensity of the upconversion.
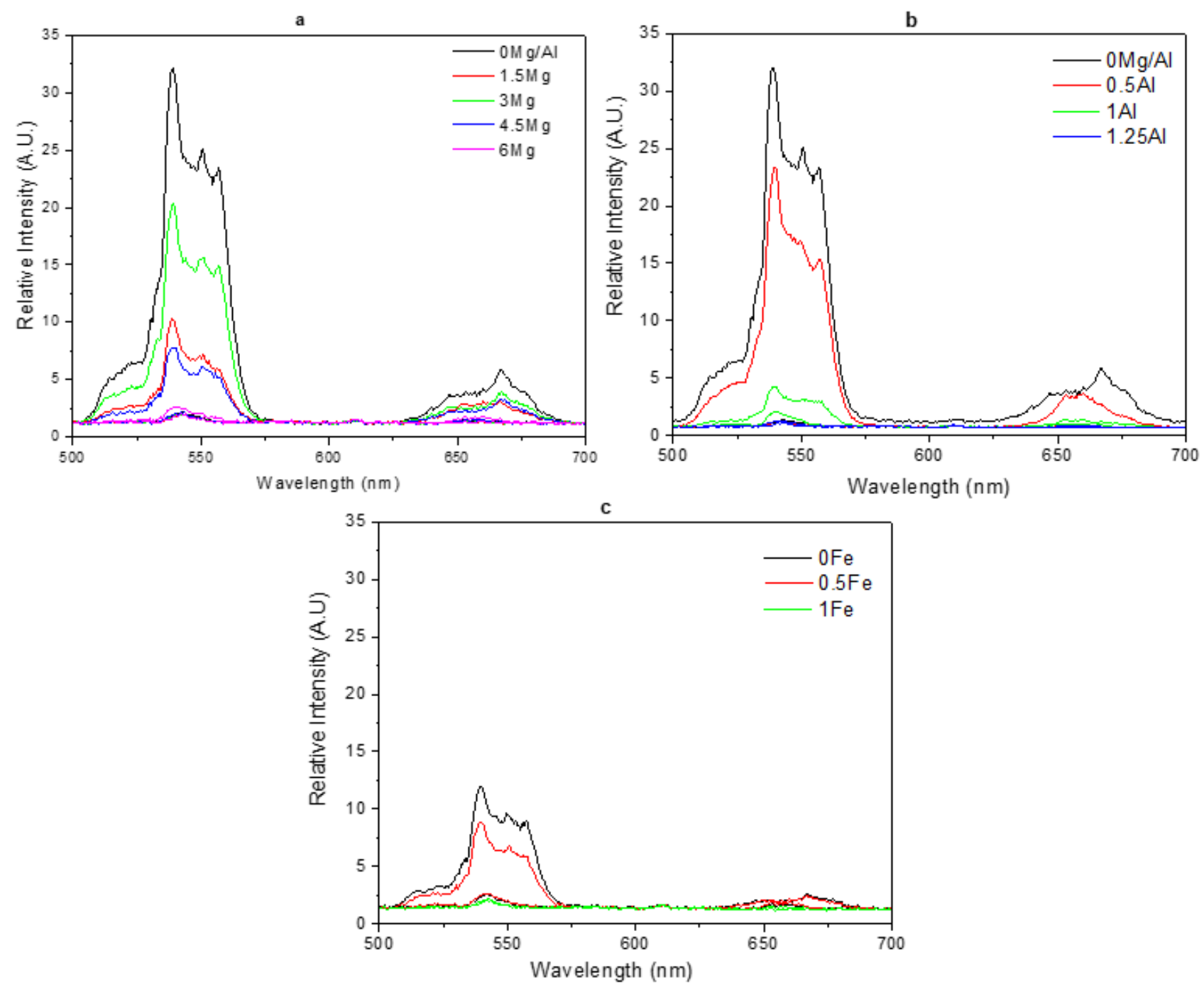

Figure 4. Upconversion spectra of the $\mathrm{Mg}(\mathbf{a}) \mathrm{Al}(\mathbf{b})$ and $\mathrm{Fe}$ (c) glasses measured prior to (solid line) and after heat-treatment at $\left(\mathrm{T}_{\mathrm{g}}+20^{\circ} \mathrm{C}\right)$ for $17 \mathrm{~h}$ and at $\mathrm{T}_{\mathrm{p}} 1 \mathrm{~h}$ (bold line) $\left(\lambda_{\mathrm{exc}}=975 \mathrm{~nm}\right)$.

As the newly developed glasses exhibit lower intensity of upconversion than the $0 \mathrm{Mg} / \mathrm{Al}$ glass after heat treatment, glasses were prepared with a larger amount of $\mathrm{Er}^{3+}$ ions, as it is well known that heavy $\mathrm{Er}^{3+}$-doping in glass leads to clustering of $\mathrm{Er}^{3+}$ ions and so to cooperative upconversion [31]. As shown in Table 3, an increase in the number of $\mathrm{Er}^{3+}$ ions increases the $T_{g}, T_{x}$ and $T_{p}$ and also the thermal stability of the glasses, suggesting that the $\mathrm{Er}^{3+}$ ions also strengthen the glass structure. Similar results were also reported in [32]. Surprisingly, the $\mathrm{ErF}_{3}$ glasses are more thermally stable than the $\mathrm{Er}_{2} \mathrm{O}_{3}$ glasses when prepared with the same amount of $\mathrm{Er}^{3+}$ ions. As suggested by [33], strong bonding of $\mathrm{Er}^{3+}$ ions with non-bringing oxygens is thus expected in the $\mathrm{ErF}_{3}$ glasses, increasing the rigidity of the network.

In order to understand the impact of the raw material on the thermal properties of the glasses, the IR spectra of the $\mathrm{Er}_{2} \mathrm{O}_{3}$ and $\mathrm{ErF}_{3}$ glasses were measured and compared. As depicted in Figure 5, the progressive addition of $\mathrm{Er}^{3+}$ ions in the glass leads to similar changes in the IR spectra than those observed in Figure 1-indicating that as for $\mathrm{Al}, \mathrm{Mg}$ and $\mathrm{Fe}$, the addition of $\mathrm{Er}^{3+}$ ions leads to the depolymerization of the phosphate network. 
Thus, the $\mathrm{Er}^{3+}$ ions are suspected to act as modifier, breaking the P-O-P bands to form $\mathrm{P}_{-} \mathrm{O}^{-}$. Er ${ }^{3+}$ ionic linkages between the $\mathrm{PO}_{4}$ units increasing $\mathrm{T}_{\mathrm{g}}$ as suggested in [34].

Table 3. Thermal properties of the investigated glasses (NA: the peak intensity is too small to estimate the size of the crystallites). Note that the $0 \mathrm{Mg} / \mathrm{Al}$ corresponds to $0.25 \mathrm{Er}_{2} \mathrm{O}_{3}$ glass.

\begin{tabular}{|c|c|c|c|c|c|c|}
\hline \multirow[b]{2}{*}{ Glass Code } & \multicolumn{4}{|c|}{ Thermal Properties } & \multirow[b]{2}{*}{$\begin{array}{l}\text { Mean Size of the Crystallites } \\
\qquad(\mathrm{nm})\end{array}$} & \multirow{2}{*}{$\begin{array}{c}\mathrm{Er}^{3+} \mathrm{Ions} / \mathrm{cm}^{3} \\
\pm 5 \% \\
\end{array}$} \\
\hline & $\begin{aligned} & \mathrm{T}_{\mathrm{g}} \\
& \pm 3\left({ }^{\circ} \mathrm{C}\right)\end{aligned}$ & $\begin{array}{c}\mathbf{T}_{\mathbf{X}} \\
\pm 3\left({ }^{\circ} \mathrm{C}\right)\end{array}$ & $\begin{aligned} & \mathrm{T}_{\mathrm{p}} \\
& \pm 3\left({ }^{\circ} \mathrm{C}\right)\end{aligned}$ & $\begin{aligned} \Delta \mathrm{T} & =\mathrm{T}_{\mathrm{x}}-\mathrm{T}_{\mathrm{g}} \\
& \pm 6\left({ }^{\circ} \mathrm{C}\right)\end{aligned}$ & & \\
\hline $0 \mathrm{Mg} / \mathrm{Al}$ & 269 & 323 & 338 & 54 & 17 & 8.19 \\
\hline $1 \mathrm{Er}_{2} \mathrm{O}_{3}$ & 281 & 357 & 376 & 76 & 26 & 33.02 \\
\hline $2 \mathrm{Er}_{2} \mathrm{O}_{3}$ & 289 & 375 & 415 & 86 & 37 & 65.84 \\
\hline $3 \mathrm{Er}_{2} \mathrm{O}_{3}$ & 298 & 384 & 466 & 86 & NA & 99.52 \\
\hline $0.5 \mathrm{ErF}_{3}$ & 266 & 337 & 352 & 71 & 17 & 8.29 \\
\hline $2 \mathrm{ErF}_{3}$ & 267 & 354 & 368 & 87 & 28 & 32.99 \\
\hline $4 \mathrm{ErF}_{3}$ & 286 & 382 & 408 & 96 & 33 & 66.95 \\
\hline $6 \mathrm{ErF}_{3}$ & 296 & 396 & 456 & 100 & NA & 101.43 \\
\hline
\end{tabular}

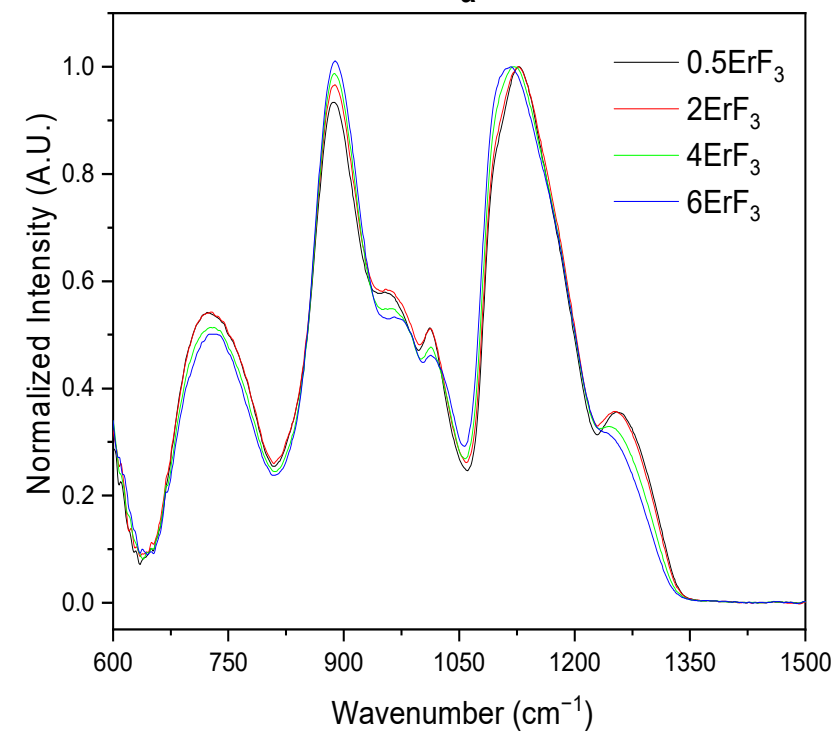

b

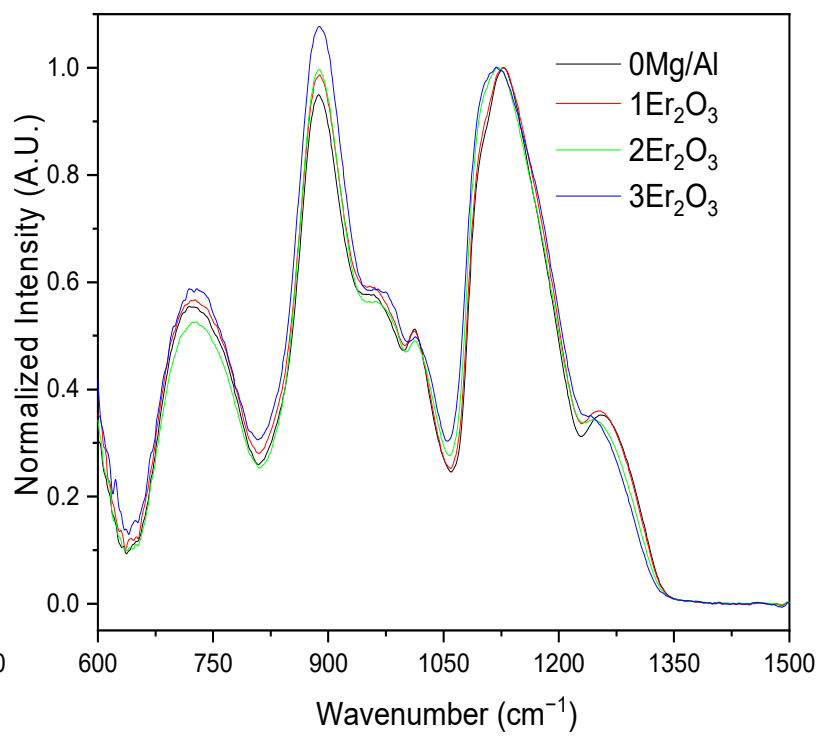

Figure 5. Normalized IR spectra of the investigated $\mathrm{ErF}_{3}(\mathbf{a})$ and $\mathrm{Er}_{2} \mathrm{O}_{3}$ (b) glasses. Note that the $0 \mathrm{Mg} / \mathrm{Al}$ corresponds to $0.25 \mathrm{Er}_{2} \mathrm{O}_{3}$ glass.

It is interesting to point out that the intensity of the bands at 880 and $\sim 965 \mathrm{~cm}^{-1}$ is lower when using $\mathrm{ErF}_{3}$ than $\mathrm{Er}_{2} \mathrm{O}_{3}$, indicating that (1) the network of the $\mathrm{ErF}_{3}$ glasses contains a lower amount of $\mathrm{Q}^{2}$ units than the network of the $\mathrm{Er}_{2} \mathrm{O}_{3}$ glasses which is also evidenced by the position of the band at $\sim 1100 \mathrm{~cm}^{-1}$ being shifted to lower wavenumber in the spectra of the $\mathrm{ErF}_{3}$ glasses and (2) the long chain structure of the phosphate network is cut to smaller rings in the $\mathrm{ErF}_{3}$ glasses. Similar changes in the structure were reported in $[24,35]$ when replacing $\mathrm{CaO}$ by $\mathrm{CaF}_{2}$ in the $\mathrm{NaPO}_{3}-\mathrm{CaO}-\mathrm{CaF}_{2}$ network. It is possible to think that the $\mathrm{ErF}_{3}$ glasses are more thermally stable than the $\mathrm{Er}_{2} \mathrm{O}_{3}$ glasses as their network is more depolymerized and contains a larger number of small rings.

As shown in Figure 6, the $\mathrm{ErF}_{3}$ and $\mathrm{Er}_{2} \mathrm{O}_{3}$ raw materials have a similar impact on the crystallization properties of the glasses; $\mathrm{CaF}_{2}, \mathrm{NaPO}_{3}$ and $\mathrm{Na}_{2} \mathrm{Ca}_{2}\left(\mathrm{P}_{2} \mathrm{O}_{7}\right) \mathrm{F}_{2}$ crystals were found in the highly $\mathrm{Er}^{3+}$ concentrated glasses after heat-treatment. The crystallites have similar sizes in the $\mathrm{ErF}_{3}$ and $\mathrm{Er}_{2} \mathrm{O}_{3}$ glasses when prepared with the same amount of $\mathrm{Er}^{3+}$ ions (Table 3). 


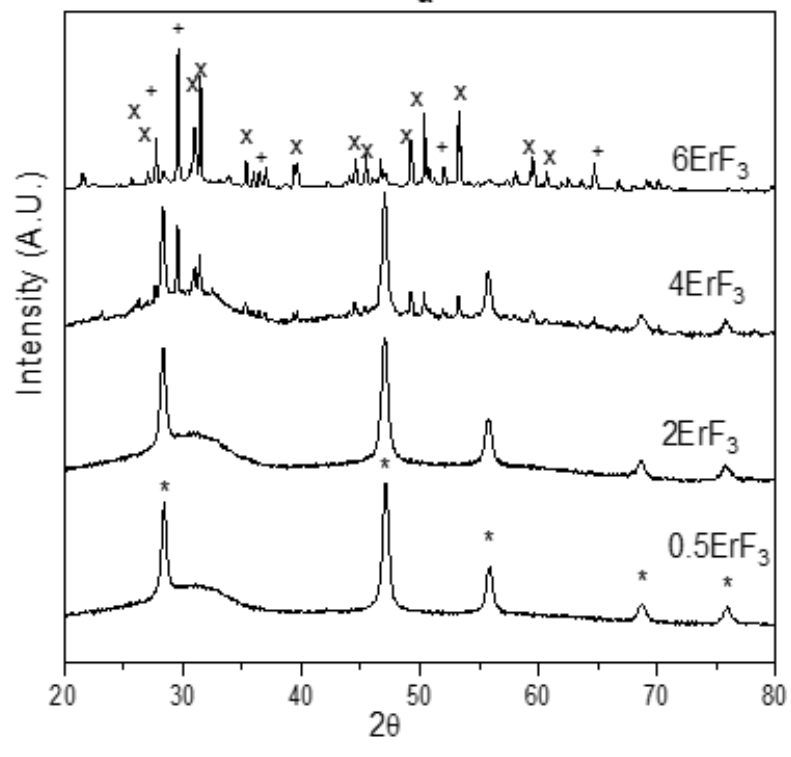

b

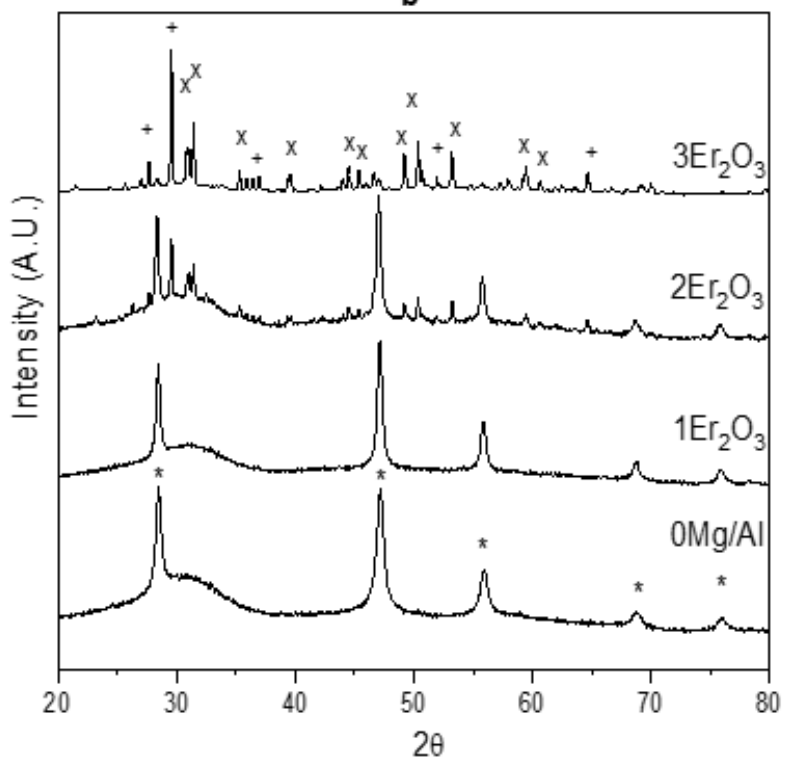

Figure 6. XRD spectra of the glasses prepared with $\mathrm{ErF}_{3}(\mathbf{a})$ and $\mathrm{Er}_{2} \mathrm{O}_{3}$ (b) after heat-treatment $\left(\mathrm{Tg}+20^{\circ} \mathrm{C}\right)$ for $17 \mathrm{~h}$ and at $\mathrm{T}_{\mathrm{p}}$ for $1 \mathrm{~h}\left(\lambda_{\mathrm{exc}}=975 \mathrm{~nm}\right)$ [Peaks correspond to * $\mathrm{CaF}_{2}$ (ICDD PDF \#00-035-0816), +NaPO 3 (ICDD PDF\#04-011-3120), $x \mathrm{Na}_{2} \mathrm{Ca}_{2}\left(\mathrm{P}_{2} \mathrm{O}_{7}\right) \mathrm{F}_{2}$ (ICDD PDF\#04-012-1844), o Ca $\mathrm{P}_{2} \mathrm{O}_{7}$ (ICDD PDF \#00-009-0345)]. Note that the 0Mg/Al corresponds to $0.25 \mathrm{Er}_{2} \mathrm{O}_{3}$ glass.

As expected, an increase in the number of $\mathrm{Er}^{3+}$ ions in the $\mathrm{ErF}_{3}$ and $\mathrm{Er}_{2} \mathrm{O}_{3}$ glasses increases significantly the intensity of the upconversion as depicted in Figure 7.
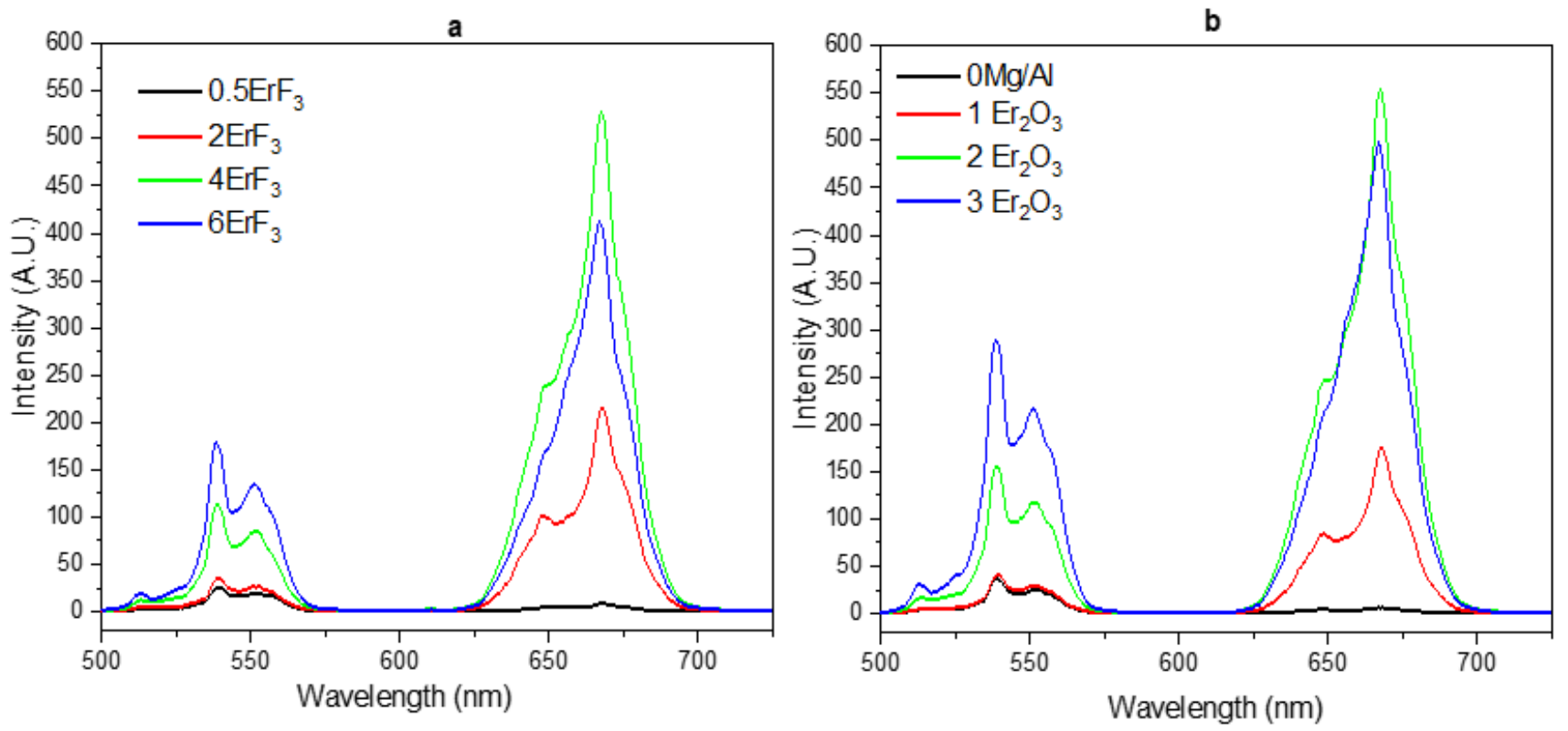

Figure 7. Upconversion spectra of the glasses prepared with $\mathrm{ErF}_{3}(\mathbf{a})$ and $\mathrm{Er}_{2} \mathrm{O}_{3}(\mathbf{b})$ after heat-treatment at $\left(\mathrm{T}_{\mathrm{g}}+20^{\circ} \mathrm{C}\right)$ for $17 \mathrm{~h}$ and at $\mathrm{T}_{\mathrm{p}}$ for $1 \mathrm{~h}\left(\lambda_{\mathrm{exc}}=975 \mathrm{~nm}\right)$. Note that the $0 \mathrm{Mg} / \mathrm{Al}$ corresponds to $0.25 \mathrm{Er}_{2} \mathrm{O}_{3}$ glass.

Interestingly, the intensity ratio of the red to green emissions increases with an increase in the concentration of $\mathrm{Er}^{3+}$ ions. This can be due to the reduction in the distance between $\mathrm{Er}^{3+}$ ions located in the $\mathrm{CaF}_{2}$ nanocrystals. Indeed, the interionic interactions are favored when the concentration of the $\mathrm{Er}^{3+}$ ions increases resulting in an efficient cross-relaxation process between erbium-erbium pairs [36]. With increasing the content of $\mathrm{Er}^{3+}$ into the crystals, the cross-relaxation probability gives rise to the populating of the ${ }^{4} \mathrm{~F}_{9 / 2}$ level, 
increasing the intensity ratio of the red emission over the green one. Similar results were reported by Chen et al. [36]. It is clearly shown that the optimum amount of $\mathrm{Er}^{3+}$ ions for the preparation of glass with high intensity of visible upconversion seems to be between $\sim 66 \times 10^{19}$ and $100 \times 10^{19} \mathrm{Er}^{3+}$ ions $/ \mathrm{cm}^{3}$ in both glass systems. Finally, it is interesting to point out that the $3 \mathrm{Er}_{2} \mathrm{O}_{3}$ glass exhibits slightly larger red and green emissions than the $6 \mathrm{ErF}_{3}$ glass while having the same amount of $\mathrm{Er}^{3+}$ ions. Thus, a larger number of $\mathrm{Er}^{3+}$ ions is expected in the $\mathrm{CaF}_{2}$ crystals precipitating in the $3 \mathrm{Er}_{2} \mathrm{O}_{3}$ glass than in the $6 \mathrm{ErF}_{3}$ glass, probably due to the less strong bonding of $\mathrm{Er}^{3+}$ ions with non-bringing oxygens in the $\mathrm{Er}_{2} \mathrm{O}_{3}$ glasses than in the $\mathrm{ErF}_{3}$ glasses as discussed earlier.

\section{Conclusions}

To conclude, novel $\mathrm{Er}^{3+}$ doped oxyfluorophosphate glasses in the $\mathrm{NaPO}_{3}-\mathrm{CaF}_{2}$ system were prepared with various amounts of $\mathrm{MgO}, \mathrm{Fe}_{2} \mathrm{O}_{3}, \mathrm{Al}_{2} \mathrm{O}_{3}, \mathrm{Er}_{2} \mathrm{O}_{3}$ and $\mathrm{ErF}_{3}$ in order to prepare thermally stable glasses which can be heat-treated into glass-ceramic with strong visible upconversion under $975 \mathrm{~nm}$ pumping. It is shown here that it is possible to tailor the glass composition to increase the thermal stability of the glass. However, due to changes in the glass structure, the tailoring of the glass composition has also a significant impact on the nucleation and growth and so on the intensity of the upconversion under $975 \mathrm{~nm}$ pumping. We demonstrate that it is possible to increase significantly the intensity of the green and red emissions by increasing the number of $\mathrm{Er}^{3+}$ ions in the glass.

Author Contributions: L.P. and W.B. designed the study. I.D. prepared the $\mathrm{Fe}, \mathrm{Mg}$ and $\mathrm{Al}$ containing glasses. N.O. prepared the Er containing glasses and performed all experimental study and wrote the manuscript. All authors have read and agreed to the published version of the manuscript.

Funding: Academy of Finland (Flagship Programme, Photonics Research and Innovation PREIN320165 and Academy Project -326418) is greatly acknowledged for the financial support.

Acknowledgments: This work made use of Tampere Microscopy Center facilities at Tampere University.

Conflicts of Interest: The authors declare no conflict of interest.

\section{References}

1. Boetti, N.G.; Scarpignato, G.C.; Lousteau, J.; Pugliese, D.; Bastard, L.; Broquin, J.-E.; Milanese, D. High concentration Yb-Er co-doped phosphate glass for optical fiber amplification. J. Opt. 2015, 17, 65705. [CrossRef]

2. Bunker, B.C.; Arnold, G.W.; Wilder, J.A. Phosphate glass dissolution in aqueous solutions. J. Non Cryst. Solids. 1984, 64, $291-316$. [CrossRef]

3. Gonçalves, M.C.; Santos, L.F.; Almeida, R.M. Rare-earth-doped transparent glass ceramics. Comptes Rendus Chim. 2002, 5, 845-854. [CrossRef]

4. De Pablos-Martín, A.; Durán, A.; Pascual, M.J. Nanocrystallisation in oxyfluoride systems: Mechanisms of crystallisation and photonic properties. Int. Mater. Rev. 2012, 57, 165-186. [CrossRef]

5. Zanotto, E.D. A bright future for glass-ceramics. Am. Ceram. Soc. Bull. 2010, 89, 19-27.

6. Shang, F.; Chen, Y.; Xu, J.; Yang, T.; Yang, Y.; Chen, G. Up-conversion luminescence and highly sensing characteristics of $\mathrm{Er}^{3+} / \mathrm{Yb}^{3+}$ co-doped borophosphate glass-ceramics. Opt. Commun. 2019, 441, 38-44. [CrossRef]

7. Saad, M.; Elhouichet, H. Good optical performances of $\mathrm{Eu}^{3+} / \mathrm{Dy}^{3+} / \mathrm{Ag}$ nanoparticles co-doped phosphate glasses induced by plasmonic effects. J. Alloys Compd. 2019, 806, 1403-1409. [CrossRef]

8. Wang, Y.; Ohwaki, J. New transparent vitroceramics codoped with $\mathrm{Er}^{3+}$ and $\mathrm{Yb}^{3+}$ for efficient frequency upconversion. Appl. Phys. Lett. 1993, 63, 3268-3270. [CrossRef]

9. Qiao, X.; Fan, X.; Wang, J.; Wang, M. Luminescence behavior of $\mathrm{Er}^{3+}$ ions in glass-ceramics containing CaF 2 nanocrystals. J. Non Cryst. Solids 2005, 351, 357-363. [CrossRef]

10. Kang, S.; Xiao, X.; Pan, Q.; Chen, D.; Qiu, J.; Dong, G. Spectroscopic properties in $\mathrm{Er}^{3+}$-doped germanotellurite glasses and glass ceramics for mid-infrared laser materials. Sci. Rep. 2017, 7, 43186. [CrossRef] [PubMed]

11. Ren, J.; Lu, X.; Lin, C.; Jain, R.K. Luminescent ion-doped transparent glass ceramics for mid-infrared light sources. Opt. Express 2020, 28, 21522-21548. [CrossRef] [PubMed]

12. Xing, Z.; Gao, S.; Liu, X.; Sun, S.; Yu, C.; Xiong, L.; Li, K.; Liao, M. Study on the structure, mechanical properties, and 2- $\mu$ m fluorescence of $\mathrm{Ho}^{3+}$-doped transparent $\mathrm{TeO}_{2}$-based glass-ceramics. J. Alloys Compd. 2016, 660, 375-381. [CrossRef]

13. Liu, X.; Zhou, J.; Zhou, S.; Yue, Y.; Qiu, J. Transparent glass-ceramics functionalized by dispersed crystals. Prog. Mater. Sci. 2018, 97, 38-96. [CrossRef] 
14. Ojha, N.; Szczodra, A.; Boetti, N.G.; Massera, J.; Petit, L. Nucleation and growth behavior of Er ${ }^{3+}$ doped oxyfluorophosphate glasses. RSC Adv. 2020, 10, 25703-25716. [CrossRef]

15. Stolov, A.; Simoff, D.A.; Li, J. Thermal Stability of Specialty Optical Fibers. J. Light. Technol. 2008, 26, 3443-3451. [CrossRef]

16. Donald, I.W.; Metcalfe, B.L.; Taylor, R.N.J. The immobilization of high level radioactive wastes using ceramics and glasses. J. Mater. Sci. 1997, 32, 5851-5887. [CrossRef]

17. Donald, I.W. Preparation, properties and chemistry of glass- and glass-ceramic-to-metal seals and coatings. J. Mater. Sci. 1993, 28, 2841-2886. [CrossRef]

18. Wei, T.Y.; Hu, Y.; Hwa, L.G. Structure and elastic properties of low-temperature sealing phosphate glasses. J. Non Cryst. Solids 2001, 288, 140-147. [CrossRef]

19. De Wild, J.; Meijerink, A.; Rath, J.K.; van Sark, W.G.J.H.M.; Schropp, R.E.I. Upconverter solar cells: Materials and applications. Energy Environ. Sci. 2011, 4, 4835-4848. [CrossRef]

20. Van Sark, W.G.; de Wild, J.; Rath, J.K.; Meijerink, A.; Schropp, R.E.I. Upconversion in solar cells. Nanoscale Res. Lett. 2013,8 , 81. [CrossRef]

21. Bingham, P.A.; Hand, R.J.; Forder, S.D. Doping of iron phosphate glasses with $\mathrm{Al}_{2} \mathrm{O}_{3}, \mathrm{SiO}_{2}$ or $\mathrm{B}_{2} \mathrm{O}_{3}$ for improved thermal stability. Mater. Res. Bull. 2006, 41, 1622-1630. [CrossRef]

22. Marasinghe, G.K.; Karabulut, M.; Ray, C.S.; Day, D.E.; Allen, P.G.; Bucher, J.J.; Shuh, D.K.; Badyal, Y.; Saboungi, M.L.; Grimsditch, M.; et al. Environment Issues and Waste Management Technologies IV (special issue). Ceram. Trans. 1999, 93, 195.

23. Zhang, L.; Ghussn, L.; Schmitt, M.L.; Zanotto, E.D.; Brow, R.K.; Schlesinger, M.E. Thermal stability of glasses from the $\mathrm{Fe}_{4}\left(\mathrm{P}_{2} \mathrm{O}_{7}\right)_{3}-$ $\mathrm{Fe}\left(\mathrm{PO}_{3}\right)_{3}$ system. J. Non Cryst. Solids 2010, 356, 2965-2968. [CrossRef]

24. Cui, S.; Massera, J.; Lastusaari, M.; Hupa, L.; Petit, L. Novel fluorophosphates glasses and glass-ceramics. J. Non Cryst. Solids 2016, 445, 40-44. [CrossRef]

25. Takebe, H.; Suzuki, Y.; Uemura, T. The effects of $\mathrm{B}_{2} \mathrm{O}_{3}$ and $\mathrm{Al}_{2} \mathrm{O}_{3}$ additions on the structure of phosphate glasses. Phys. Chem. Glas. Eur. J. Glas. Sci. Technol. Part B 2014, 55, 207-210.

26. Raguenet, B.; Tricot, G.; Silly, G.; Ribes, M.; Pradel, A. The mixed glass former effect in twin-roller quenched lithium borophosphate glasses. Solid State Ionics 2012, 208, 25-30. [CrossRef]

27. Holzwarth, U.; Gibson, N. The Scherrer equation versus the "Debye-Scherrer equation". Nat. Nanotechnol. 2011, 6, 534. [CrossRef] [PubMed]

28. Li, X.; Xu, D.; Liu, X.; Guo, H. Dual valence Eu-doped phospho-alumino-silicate glass-ceramics containing $\mathrm{Ba}_{3} \mathrm{AlO}_{3} \mathrm{PO}_{4}$ nanocrystals for W-LEDs. RSC Adv. 2017, 7, 53839-53845. [CrossRef]

29. Auzel, F. Upconversion and Anti-Stokes Processes with f and d Ions in Solids. Chem. Rev. 2004, 104, 139-174. [CrossRef]

30. Szczodra, A.; Mardoukhi, A.; Hokka, M.; Boetti, N.G.; Petit, L. Fluorine losses in $\mathrm{Er}^{3+}$ oxyfluoride phosphate glasses and glass-ceramics. J. Alloys Compd. 2019, 797, 797-803. [CrossRef]

31. Seneschal, K.; Smektala, F.; Bureau, B.; Floch, M.L.; Jiang, S.; Luo, T.; Lucas, J.; Peyghambarian, N. Properties and Structure of High Erbium Doped Phosphate Glass for Short Optical Fibers Amplifiers. Mater. Res. Bull. 2005, 40, 1433-1442. [CrossRef]

32. Ersundu, A.E.; Karaduman, G.; Çelikbilek, M.; Solak, N.; Aydın, S. Effect of Rare-Earth Dopants on the Thermal Behavior of Tungsten Tellurite Glasses. J. Alloys Compd. 2010, 508, 266-272. [CrossRef]

33. Nazabal, V.; Todoroki, S.; Nukui, A.; Matsumoto, T.; Suehara, S.; Hondo, T.; Araki, T.; Inoue, S.; Rivero, C.; Cardinal, T. Oxyfluoride tellurite glasses doped with erbium: Thermal analysis, structural organization and spectral properties. J. Non Cryst. Solids 2003, 325, 85-102. [CrossRef]

34. Shyu, J.-J.; Chiang, C.-C. Effects of $\mathrm{Er}_{2} \mathrm{O}_{3}$ Doping on the Structure, Thermal Properties, and Crystallization Behavior of SnO- $\mathrm{P}_{2} \mathrm{O}_{5}$ Glass. J. Am. Ceram. Soc. 2010, 93, 2720-2725. [CrossRef]

35. Nommeots-Nomm, A.; Boetti, N.G.; Salminen, T.; Massera, J.; Hokka, M.; Petit, L. Luminescence of Er ${ }^{3+}$ doped oxyfluoride phosphate glasses and glass-ceramics. J. Alloys Compd. 2018, 751, 224-230. [CrossRef]

36. Chen, D.; Wang, Y.; Yu, Y.; Ma, E.; Bao, F.; Hu, Z.; Cheng, Y. Influences of $\mathrm{Er}^{3+}$ content on structure and upconversion emission of oxyfluoride glass ceramics containing $\mathrm{CaF}_{2}$ nanocrystals. Mater. Chem. Phys. 2006, 95, 264-269. [CrossRef] 